\title{
Iuno Regina in Aeneid 12: Evocatio and Reconciliation
}

Iuno Regina in Aen. 12: Evocatio e riconciliazione

\section{María Emilia Cairo}

\section{(2) OpenEdition}

\section{Journals}

Electronic version

URL: https://journals.openedition.org/mythos/2979

DOI: 10.4000/mythos.2979

ISSN: 2037-7746

\section{Publisher}

Salvatore Sciascia Editore

\section{Electronic reference}

María Emilia Cairo, "Iuno Regina in Aeneid 12: Evocatio and Reconciliation", Mythos [Online], 15| 2021,

Online since 15 December 2021, connection on 15 December 2021. URL: http://

journals.openedition.org/mythos/2979; DOI: https://doi.org/10.4000/mythos.2979

This text was automatically generated on 15 December 2021.

Mythos 


\section{Iuno Regina in Aeneid 12: Evocatio and Reconciliation}

Iuno Regina in Aen. 12: Evocatio e riconciliazione

María Emilia Cairo

\section{Introduction}

1 Throughout the Aeneid, Juno is featured as the main opponent to Aeneas' foundational endeavors. From the proem, it is stressed that the sufferings that the hero must endure are caused saeuae memorem Iunonis ob iram (Aen. 1.4). ${ }^{1}$ In Aen. 1.12-32 the reasons behind Juno's terrible hatred are explained. On the one hand, she knows that Aeneas' descendants will destroy Carthage, a city that worships her especially; on the other hand, she still remembers both the judgement of Paris, in which she was not chosen as the most beautiful goddess, and the abduction of Ganymede by her husband Jupiter. Juno is depicted since the beginning of the poem as the Trojans' archenemy, both for "mythical" reasons - Paris, Ganymede, and Aeneas were Trojans - and "historical" ones - the future Punic Wars in which the Romans will destroy her beloved African city. ${ }^{2}$

2 Juno deploys her opposition to Aeneas throughout the entire poem; ${ }^{3}$ nevertheless, towards the end of Book 12, we find the dialogue with Jupiter in which she agrees that Aeneas can finally settle in Italy. In his classic article "The Reconciliations of Juno" (1984), Denis Feeney examined the episode of the agreement between Juno and Jupiter in Book 12 and observed, going back to Servius, that such reconciliation is by no means definitive, since the Punic Wars are yet to come. This pacification is thus only apparent and short-lived, since the goddess will be hostile to the Romans again, in her role as protector of Carthage. 


\section{The Reconciliation of Juno in Aeneid 12 and Servius' reading}

3 Let us start by recalling the passage in Aeneid 12. Turnus and Aeneas are about to begin their duel, when the narrative moves to the divine realm. Jupiter addresses Juno in order to admonish her, but in a friendly tone. He starts asking when will she cease to torment Aeneas, considering that his victory and subsequent apotheosis are backed by fatum (12.793-799). The king of the gods then forbids her to go further (12.806: ulterius temptare veto), but he skillfully explains that he aims for Juno's own well-being (12.800-802: desine iam tandem precibusque inflectere nostris, / ne te tantus edit tacitam dolor et mihi curae / saepe tuo dulci tristes ex ore recursent). That is, Jupiter, as a good king, puts an end to her hostility while looking at the same time to settle an agreement with a goddess that is, at the same time, his wife and sister, his equal, the queen of the gods. ${ }^{4}$

Juno's answer includes first an acknowledgement of Jupiter's will as the reason for her leaving the battlefield (12.808-818) and secondly her assent to Aeneas' settlement in Latium through "marriages" and "pacts", on condition that every Trojan element is erased from the Romana propago (12.819-828). We will return to this problem later.

5 Jupiter is pleased (12.829: subridens) and recognizes a sign of Juno's majesty in her passionate anger. ${ }^{5} \mathrm{He}$ promises to give her whatever she wishes, acknowledging that he has been defeated, although willingly (12.833: uictusque uolensque). ${ }^{6}$ The final agreement is that the Ausonians retain their language and customs, as well as their name, and that the Trojans are subsumed within the Italian identity, under the name of Latini. ${ }^{7}$ Finally, he grants that Romans will be recognized by all nations for their remarkable piety, and that they will worship Juno like no other people. ${ }^{8}$ The dialogue closes with Juno's consent (12.841: adnuit his Iuno) - the goddess, satisfied (12.841: laetata ${ }^{9}$ ), leaves the place, abandoning Turnus to his fate.

6 It is at this point that Servius introduces his remarks about the non-definitive character of the reconciliation between Juno and Aeneas' descendants: iste quidem hoc dicit; sed constat bello Punico secundo exoratam Iunonem, tertio uero bello a Scipione sacris quibusdam etiam Romam esse translatam. ${ }^{10}$ If in future Roman history Juno will favor the Carthaginians, this agreement with Jupiter will not have eternal validity. Moreover, when commenting on Aen. 1.281, Servius had pointed out that consilius in melius referet referred to an Ennian passage in which the goddess is placated thanks to the sacrifices carried out by Scipio, situating the reconciliation in the historical context of the Punic Wars. ${ }^{11}$ Feeney's article proposes the fundamental intertextuality with Ennius' Annales in regards to Juno as Carthage's tutelar deity. He understands, following W. R. Johnson (1976), that the agreement in Book 12 only refers to Aeneas' settlement in Latium in the near future - it is the end of her "mythical" hatred, the one motivated by her hostility towards Troy since the Homeric poems. But her "historical" hate has not ceased, and the goddess will continue causing problems to the Romans, in an enmity-reconciliation dynamic that will last throughout the history of Rome until Scipio's episode. ${ }^{12}$

7 When Servius (ad Aen. 12.841) mentions the making of supplications to Juno to obtain her favor, and the transfer of her statue to Rome in order to establish a new cult, he describes the ceremony of evocatio. It is not the only time that Servius makes mention of this ritual custom in his Commentary: he has done it twice in the context of the Trojan War story in Book 2. When explaining the introduction of the wooden horse told in 
2.244-245, instamus tamen immemores caecique furore / et monstrum infelix sacrata sistimus arce, he states that immemores caecique furore points to the fact that the Trojans have been abandoned by their gods, and then explains secundum disciplinam carminis Romani, quo ex urbibus hostium deos ante evocare solebant. A little later, in his commentary on Aen. 2.351, excessere omnes adytis arisque relictis / di quibus imperium hoc steterat, Servius uses the verb evocare once again: ante expugnationem evocabantur ab hostibus numina propter vitanda sacrilegia.

Considering these three statements by Servius, it is concluded that evocatio was a religious operation carried out in a war context before a city was captured, through which the invader army "called out" the tutelar deities in order to avoid a sacrilege, i.e. to prevent the gods from being a captive too. In the case of the Scipio episode, the transfer of the goddess' simulacrum to Rome is also included.

Macrobius also comments on Aen. 2.351-352 in Sat. 3.9. He says that the reference to the gods leaving Troy stems de vetustissimo Romanorum more et de occultissimis sacris and then he explains (Sat. 3.9.2): ${ }^{13}$

constat enim omnes urbes in alicuius dei esse tutela, moremque Romanorum arcanum et multis ignotum fuisse ut, cum obsiderent urbem hostium eamque iam capi posse confiderent, certo carmine evocarent tutelares deos; quod aut aliter urbem capi posse non crederent, aut etiam si posset, nefas aestimarent deos habere captivos.

For it is well known that every city is under the protection of some deity, and it is an established fact that it was the custom of the Romans (a secret custom and one that is unknown to many) by means of a prescribed formula to call forth the tutelary deities of an enemy city which they were besieging and now felt confident of being able to take; either because they believed that unless they did so the city could not be taken after all or rather because, were the capture possible, they held it to be an offense against the divine law to make prisoners of gods ${ }^{14}$.

To Servius' definition of evocatio as a means to prevent the inset of divine anger, Macrobius adds another possible explanation - the consent of the tutelar deity as a requisite for the conquest: ${ }^{15}$ if Troy is doomed to fall, it is due to the fact that the gods have decided to leave it unprotected. Macrobius then introduces the text of the carmen evocationis (Sat. 3.9.7-8) ${ }^{16}$, which refers to the taking of Carthage - it could be the text pronounced by Scipio Aemilianus in 146 BC..$^{17}$

In sum, both Servius and Macrobius, when commenting on Vergil's description of the fall of Troy in Book 2, refer to the ritual of evocatio. Servius also mentions the transfer of the Carthaginian Juno to Rome in the Third Punic War as the historical event referred to in Book 12.

12 I will not linger here in disquisitions on the definition of evocatio and the various methodological issues that its study involves - Nadia Berti, Alain Blomart, Gabriela Gustaffson, Giorgio Ferri, and Edoardo Grandi have studied this ritual in great detail from different theoretical approaches ${ }^{18}$. For the purposes of this paper, it is enough to remember that the term evocatio designated a ritual action performed in a military context $^{19}$, the purpose of which was to invite the tutelar deity of an enemy city ${ }^{20}$ to abandon their protégés, in order to grant a Roman victory ${ }^{21}$. In exchange, Romans would perform a votum ${ }^{22}$ promising that deity a new temple or cult in Rome, better than the one she/he received so far. ${ }^{23}$ As a result, new gods and goddesses, originally "foreign" 24 , were incorporated into the Roman pantheon. Sometimes the simulacra 
placed in the native cities were transferred to the Urbs ${ }^{25}$, which was in itself a display of the great Roman power that conquered both nations and deities. ${ }^{26}$

In his commentary on Aen. 12, Servius understands Juno exclusively as the Carthaginian tutelar deity. ${ }^{27}$ It is certainly appropriate to analyse the Vergilian Juno considering her Caelestis advocation, ${ }^{28}$ in view of the way in which Juno's fondness for Carthage is described in Aen. 1.12-18:

Vrbs antiqua fuit (Tyrii tenuere coloni)

Karthago, Italiam contra Tiberinaque longe

ostia, dives opum studiisque asperrima belli,

quam Iuno fertur terris magis omnibus unam

posthabita coluisse Samo. hic illius arma,

hic currus fuit; hoc regnum dea gentibus esse,

si qua fata sinant, iam tum tenditque fouetque.

Once, an old city existed, and Tyrian settlers controlled it:

Carthage, a distant menace to Italy, facing the Tiber's

Estuary, rich in resources, ferocious in practice of warfare.

Juno reportedly cherished this one land more than all others, $\quad 15$

Even than Samos. In Carthage she kept both her chariot and weapons.

This was her candidate city to rule as the king of all nations

If fate allowed. For this role she was grooming it even in those days. ${ }^{29}$

This preference is reflected in the deep veneration that Dido and the Carthaginians show for her, as it can be appreciated from the magnificent temple they have erected in her honor, contemplated by Aeneas during his walk across the city. ${ }^{30}$ Besides, Dido's curse to Aeneas when he leaves, that culminates with pugnent ipsique nepotesque (4.629), provides a reason for the historic Punic Wars, which, in turn, explains Servius' reference to Scipio when commenting on the reconciliation of Juno in Book 12.

However, it is my understanding that in Book 12 it is possible to find an allusion to another historical event - not only to the evocatio of Juno Caelestis at the end of the Third Punic War, but also to the ritual performed by Camillus in 396 BCE in order to obtain Iuno Regina's support in the conquest of Veii, described in Book 5 of Livy's Ab urbe condita. ${ }^{31}$

This proposal is based on two elements. First, Juno's cult was extended throughout Italy, with evidence of temples and rituals in different cities, and records of evocationes refer to Juno or goddesses equivalent to her. Secondly, in the dialogue with Jupiter in Aeneid 12, Juno's request revolves around the oblivion of Troy and the centrality of the Italic element in the future Roman identity, without any mention of Carthage at all.

\section{Juno and her evocationes}

First of all, it should be remembered that Juno was known in Rome not only as a Carthaginian deity, Iuno Caelestis, the equivalent of Tanit, but also as a goddess that was especially worshipped in different Italian cities from ancestral times. ${ }^{32}$ Latin cities such as Aricia, Lanuvium, Laurentum, Praeneste, Tibur, Tusculum, Norba, and Gabii are registered among those where Juno enjoyed the highest veneration. In Rome itself, a temple was dedicated to her on the Capitoline Hill, as Iuno Regina, and another one in the Esquiline, as Iuno Lucina. ${ }^{33}$ These epithets, together with Sospita, Populona, Regina Matrona etc, show the goddess' main features: first, her feminine character and her connection with maternity and birth; secondly, her warlike side; finally, her role as a 
queen. Romans were aware of her immense power and therefore took the precaution of turning the profound influence of this goddess in their favor. ${ }^{34}$ It is no coincidence that Juno (or her equivalents Uni, Tanit, Hera ${ }^{35}$ ) predominates in the evocation records according to Dumézil (1974: 299), she was "the most puzzling deity". The episode of the conquest of Veii includes the evocatio of the city's tutelar deity, Iuno Regina, performed by Camillus. After a ten-year siege, the victory is only attained when the goddess agrees to support the Romans, in exchange for a new cult in Rome.

Let us remember briefly this historical episode, such as it is described by Livy in the first part of Book 5 of $A b$ urbe condita. ${ }^{36}$ The description of the evocatio itself is found in chapters 21-22, but from the very beginning of Book 5 the presence of religious and ritual elements is remarkable. ${ }^{37}$ In ch. 1 , the Romans are presented as a pious people, in contrast to the inhabitants of Veii, whose king has suspended the celebration of games; ${ }^{38}$ in ch. 13 the Sibylline Books are consulted and a lectisternium is celebrated in order to placate the gods and ask them to change the weather; ${ }^{39}$ the prodigium of Lake Albanus, that causes the sending of an embassy to Delphi, is narrated in $15-17 ;^{40}$ in ch. 18 , the rumour of defeat puts in motion a series of rites and pleas carried out by the Roman matrons ${ }^{41}$; in ch. 19 , Camillus makes a vow before the Senate that, in the event he takes Veii, he would celebrate great games and that he would rebuild and dedicate Mater Matuta's temple. ${ }^{42}$ All these elements help to create an atmosphere in which the religious element acquires greater and greater relevance, until reaching the evocatio of Juno as the highlight of the episode. The central role played by religion in Book 5 is expressed at the beginning of chapter 19: it is stated that Veios fata adpetebant, while Camillus is described as fatalis $d u x,{ }^{43}$ an adjective that connects him with none other than Aeneas, the legendary founder of the Roman lineage. ${ }^{44}$ The conquest of Veii, sanctioned by fatum and achieved thanks to the piety of the Romans, is presented as a new foundational milestone. ${ }^{45}$

The evocatio ritual is described in chapter 21 . The definitely epic style of this account is due to the fact that both Livy and Vergil share a worldview according to which men can communicate with the gods through rituals and prayers. ${ }^{46}$ Camillus takes the auspices, promises Apollo a part of the booty, and calls Juno as follows (5.21.3):

te simul, Iuno regina, quae nunc Veios colis, precor, ut nos victores in nostram tuamque mox futuram urbem sequare, ubi te dignum amplitudine tua templum accipiat.

At the same time, Juno Regina, you who now dwell in Veii, I pray that you follow us in our victory into the city that is ours and will soon be yours, where there will be a temple worthy of your greatness to receive you ${ }^{47}$.

After the invitation to support the Romans and the promise of a new temple, the final attack is undertaken: Romans enter Veii through the cuniculus devised by Camillus and take the city. The conquest, narrated right after the description of the evocatio, is seen by the reader as a result of Juno's favour. However, her consent is expressed again in chapter 22, when the Romans remove the simulacrum from its temple in order to transfer it to Rome. In the description of this operation, Roman piety and religious observance are especially highlighted: they proceed colentium magis quam rapientium modo. To remove the cult image, they choose a group of young men dressed in white, ${ }^{48}$ which shows the adaptation of the cult to a Roman custom - according to local tradition, only certain kinds of priests was allowed to touch the image. ${ }^{49}$ Roman soldiers perform the rite religiose and ask the goddess whether she is willing to go to Rome before removing the image. The affirmative answer of the statue is presented by 
Livy as a rumor, in order to distance himself from an event that could be understood as too implausible for a historical account (5.22.5-6):

dein cum quidam seu spiritu divino tactus seu iuvenali ioco "visne Romam ire, Iuno?" dixisset, adnuisse ceteri deam conclamaverunt. inde fabulae adiectum est vocem quoque dicentis velle auditam.

Then one of them, either under divine inspiration or in youthful jest, said, "Juno, do you want to go to Rome?" At this, all the others cried out that the goddess had nodded her assent. An addition was later made to the tale that a voice was also heard to say that she was willing.

21 Juno's consent, the consequence of which is the possibility of finally taking the city after ten years, manifests itself through her simulacrum, that nods (adnuisse) and speaks (vocem). Her willingness to follow the Romans appears again later, when the soldiers transfer the statue: it seems lighter than usual, as if it moved by itself, showing no opposition and causing no effort to those carrying it. ${ }^{50}$ In this respect, it is possible to underline a fundamental difference between this episode and the account of the fall of Troy, with which it is usually compared: while the Palladium is taken by force, Juno's simulacrum leaves the city willingly. ${ }^{51}$ The passage ends with the confirmation of the fulfilment of the promise of the new temple..$^{52}$ It is also stated that Veii falls because of the departure of its guardian goddess..$^{53}$

The historical episode of 396 BCE such as it is narrated by Livy, records an evocation ritual of an Italic Juno, and thus confirms that the reconciliations between this goddess and the Romans are not limited to those that occurred in her role as a protector of the Carthaginians.

\section{Juno Regina in Aeneid 12}

23 As has been pointed out above, the dialogue between Jupiter and Juno at the end of Aeneid 12 revolves around the possibility that Aeneas settles in Latium and the role that the Trojan past will play in the future Roman culture. Juno's agreement -her "reconciliation"- is linked to Jupiter accepting the prominence of the Italic element in forging the creation of this new identity (12.819-828):

illud te, nulla fati quod lege tenetur, pro Latio obtestor, pro maiestate tuorum:

cum iam conubiis pacem felicibus (esto)

component, cum iam leges et foedera iungent, ne vetus indigenas nomen mutare Latinos neu Troas fieri iubeas Teucrosque vocari aut vocem mutare viros aut vertere vestem. sit Latium, sint Albani per saecula reges, sit Romana potens Itala virtute propago: occidit, occideritque sinas cum nomine Troia.

But, I entreat you, on Latium's behalf, on behalf of your own kin's Grandeur, for something encompassed by none of fate's legal provisions. 820 When, and so be it, they settle their peace in fulfilment of marriage, When they shape treaties and laws in their confederation together, Don't require those who were born here, the Latins, to alter their ancient Name, become "Trojans", be known as "The Teucrians", or alter their language. Don't make them change their traditional dress. Let Latium continue, 825 Let there be Alban kings who will span all the centuries. And let 
Roman stock get its strength from Italian concepts of courage.

Troy is destroyed. Now permit Troy's name to share her destruction. states:

Juno agrees for Aeneas and his men to settle in Latium, as long as the local element is the main feature of future Romans. Nothing Trojan should remain: ${ }^{54}$ the Roman propago will be illustrious because it will inherit the main traits of Itala virtus. ${ }^{55}$ In Juno's request it is her Italian identity that has with special prominence - the requirements she imposes have nothing to do with the future of Carthage or with Dido's people, she refers exclusively to her sympathy for Italy.

Juno's Italic essence is highlighted by Jupiter, who calls her germana Iovis Saturnique altera proles (12.830), ${ }^{56}$ underlining their ties of kinship as brother and sister, and as Saturn's children. It should be remembered the story about Saturn that Evander tells Aeneas in 8.314-336: this god came to Italy fleeing from Mount Olympus, arma Iovis fugiens et regnis exsul ademptis, i. e., as an exile forced to settle in a new land. The name of the place is connected with this story, since, according to Virgil, Latium derives from the verb lateo, "to lurk, be or lie hidden or concealed", because Saturn could find in that land a place to be safe. ${ }^{57}$ During his reign, he gave laws to a previously wild people and achieved the establishment of a peaceful golden age. The fact that Jupiter mentions Saturn precisely here underlines the close connection between Juno's Italic identity and the defense of her people. ${ }^{58}$

Throughout the poem's second half, this image of Juno as an Italian goddess takes precedence, which is evidenced by the frequent occurrences of the epithet Saturnia in Books 7-12. As MacKay (1956: 60) observed, the mentions of Juno appear balanced throughout the poem (28 occurrences in Books 1-6 and 21 in Books 7-12), but the juncture Saturnia Iuno is notoriously more frequent in the second half - 12 occurrences, against only 4 in Books 1-6. ${ }^{59}$ Regarding this passage in particular, MacKay (1956: 60)

In the final celestial reconciliation, it is Saturnia (xii.807) that accepts the decrees of Jupiter, but with the explicit understanding (pro Latio obtestor, xii.820) that the indigenous Latins, whose royal family, we know, also derives from Saturn (vii. 45-49), shall retain their name, their language, and their garb, their political power, and their racial identity; and it is on receipt of this assurance from Jove that Juno (no longer Saturnia, for the old order is doomed) gladly accepts the new dispensation.

Both this insistence on the Italic identity of Juno in the second half of the Aeneid, and the request of the goddess that the Italic element may prevail in the future Rome, support the hypothesis that the memory of the evocatio of Iuno Regina performed by Camillus is also present here.$^{60}$ Moreover, the fact that Jupiter remarks that both share the same dignity may be understood as a reference to Juno's advocation as Regina: given that Jupiter is rex, if Juno is equal to him, she is, therefore, regina - the poem closes describing her as in the beginning (1.9: regina deum). Besides, it worth remembering that the temple dedicated to Iuno Regina is one of those restored by Augustus, according to his Res Gestae. ${ }^{61}$

To sum up, this passage of Book 12, in which Juno accepts to support the Aeneadae in exchange for her future Roman worship, may be understood as the poetic version of a Roman traditional ritual. The possibility that a hostile deity might become an ally of the Romans finds a literary precedent in the Aeneid. 


\section{Conclusion} "evokes" Jupiter to move him from a pro-Trojan position (he is both Cybele's son ${ }^{63}$ and Venus' father ${ }^{64}$ ) to one that has the Italic element in a central role. When admitting that he has been defeated willingly, Jupiter gets reconciled with the Italic position that Juno defends.

34 It is, therefore, possible to understand this passage from Aeneid 12 as an aetiology of evocatio, a ritual mechanism through which it was possible to assure a former hostile deity's support and transfer him/her into the Roman pantheon. In this dialogue, a Roman identity is configured not only in ethnic terms - the oblivion of every Trojan component, the preeminence of Italic elements - but also in matters of religion: Romans will worship every deity that supports them, in a dynamic of incorporation that manages to include even Juno herself. To conclude, it can be asserted that a religion with images in motion is represented in mythical and poetic terms in this dialogue. 


\section{BIBLIOGRAPHY}

AHL 2007: F. Ahl, Virgil. Aeneid. Translated with Notes by Frederick Ahl, Oxford 2007.

ALVAR 1985: J. Alvar, «Matériaux pour l'étude de la formule sive deus, sive dea», Numen 32.2 (1985),

236-273.

AMERASINGHE 1953: C. W. Amerasinghe, «Saturnia Iuno: its Significance in the Aeneid», Greece \&Rome 22.65 (1953), 61-69.

AMES AND DE SANTIS 2011: C. Ames and G. De Santis, «La memoria histórica de la diversidad étnica italiana en Eneida de Virgilio», Circe 15 (2011), 41-54.

ANDO 2002: C. Ando, «Vergil's Italy: Ethnography and Politics in First-Century Rome», in D. S. Levene and D. P. Nelis (eds.), Clio and the Poets. Augustan Poetry and the Traditions of Ancient Historiography, Leiden-Boston-Köln 2002, 123-142.

ANDo 2008: C. Ando, The Matter of the Gods. Religion and the Roman Empire, Berkeley 2008.

BeARD, NoRTh AND PRICE 1998: M. Beard, J. North and S. Price, Religions of Rome. Vol. I: A History, Cambridge 1998.

BERTI 1990: N. Berti, «Scipione Emiliano, Caio Gracco e l'evocatio di Giunone da Cartagine», Aevum 64 (1990), 69-75.

BETTINI 2005: M. Bettini, «Un'identità 'troppo compiuta'. Troiani, Latini, Romani e Iulii nell'Eneide», Materiali e discussioni per l'analisi dei testi classici 55 (2005), 77-102.

BLoch 1972: R. Bloch, «Héra, Uni, Junon en Italie centrale», Comptes rendus des séances de l'Académie des Inscriptions et Belles-Lettres 116.2 (1972), 384-396.

BlOMART 1997: A. Blomart, «Die evocatio und der Transfer 'fremder' Götter von der Peripherie nach Rom», in H. Cancik and J. Rüpke (eds.), Römische Reichsreligion und Provinzialreligion, Tübingen 1997, 99-111.

BOUCHÉ-LECLERCQ 1907: A. Bouché-Leclercq, s. v. Pontifices, DAGR IV.1, 567-578.

CAIRO 2016: M. E. Cairo, «Memoria troyana e identidad romana en Eneida. Una lectura de los diálogos entre Júpiter y Venus (I, 233-304) y entre Júpiter y Juno (XII, 791-842)», Auster. Revista del Centro de Estudios Latinos 21 (2016), 95-110.

CANCIK 2004: H. Cancik, «Ein Volk gründen. Ein myth-historisches Modell in Vergils Aeneis», in A. Bierl, A. Schmitt, and A. Willis, Antike Literatur in neuer Deutung, Munich-Leipzig, 2004, 307-323.

ColemAN 1982: R. Coleman, «The Gods in the Aeneid», Greece \& Rome 29.2 (1982), 143-168.

DAVIES 1969: P. V. Davies, Macrobius. The Saturnalia, New York-London 1969.

DELLA CORTE 1983: F. Della Corte, «Giunone, come personaggio e come dea, in Virgilio», Atene e Roma 28 (1983), 21-30.

DuMÉZIL 1974: G. Dumézil, La Religion romaine archaïque, Paris 1974.

EDEN 1975: P. T. Eden, A Commentary on Virgil: Aeneid VIII, Leiden 1975.

EGAN 2012: R. Egan, «Insignes Pietate et Armis: The Two Camilli of the Aeneid», Vergilius 58 (2012), 21-52. 
FEENEY 1984: D. C. Feeney, «The Reconciliations of Juno», Classical Quarterly 34 (1984), 179-194.

FEENEY 1991: D. C. Feeney, The Gods in Epic. Poets and Critics of the Classical Tradition, Oxford 1991.

FEENEY 2007: D. C. Feeney, «The History of Roman Religion in Roman Historiography and Epic», in J. Rüpke (ed.), A Companion to Roman Religion, Oxford-Malden 2007, 129-142.

FERRI 2006: G. Ferri, «L'evocatio romana. I problemi», Studi e materiali di storia delle religioni 72 (2006), 205-240.

FERRI 2009: G. Ferri, «Giunone Celeste», Storia, Antropologia e Scienze del linguaggio 24.1-2 (2009), 181-202.

FERRI 2010a: G. Ferri, Tutela segreta ed evocatio nel politeismo romano, Roma 2010.

FERRI 2010b: G. Ferri, Tutela urbis. Il significato e la concezione della divinità tutelare cittadina nella religione romana, Stuttgart 2010.

FRATANTUONO 2018: L. M. Fratantuono, «A Furious Fury: Virgil's Camilla, Livy's Camillus, and the reconciliations of Juno», in M. C. English and L. M. Fratantuono, Pushing the Boundaries of Historia, London-New York 2018, 172-184.

Fratantuono And Alden SMith 2018: L. M. Fratantuono and R. Alden Smith, Virgil, Aeneid 8. Text, Translation, and Commentary, Leiden-Boston 2018.

GAERTNER 2008: J. F. Gaertner, «Livy's Camillus and the Political Discourse of the Late Republic», Journal of Roman Studies 98 (2008), 27-52.

GeLORMini 2009: N. Gelormini, Augusto. Hechos. Edición trilingüe, Buenos Aires 2009.

GLINISTER 2000: F. Glinister, «Sacred rubbish», in E. Bispham and C. Smith (eds.), Religion in Archaic and Republican Rome and Italy, Edinburgh 2000, 54-70.

GRANDI 2015: E. Grandi, La religione romana e le pratiche dell'evocatio, PhD dissertation, Firenze 2015.

GUSTAFSSON 2000: G. Gustafsson, Evocatio Deorum. Historical and Mythical Interpretations of Ritualised Conquests in the Expansion of Ancient Rome, PhD dissertation, Historia Religionum 16, Uppsala 2000. HENRY 1989: E. Henry, The Vigour of Prophecy. A Study of Vergil's Aeneid, Bristol 1989.

HICKSON 1993: F. Hickson, Roman Prayer Language. Livy and the Aeneid of Vergil, Wiesbaden 1993.

HILD 1900: J. A. Hild, s. v. Juno, DAGR III.1, 1900, 668-690.

HILLEN 2007: H. J. Hillen, T. Livius. Römische Geschichte. Buch IV-VI, Düsseldorf-Zurich 2007.

JoHnson 1976: W. R. Johnson, Darkness Visible. A Study of Vergil's Aeneid, Berkeley-Los AngelesLondon 1976.

JoHnSTON 1980: P. Johnston, Vergil's Agricultural Golden Age. A Study of the Georgics, Leiden 1980. JoHNSTON 2015: P. Johnston, «Saevae memorem Iunonis ob iram: Juno, Veii, and Augustus», Acta Antiqua Academiae Scientiarum Hungaricae 55 (2015), 167-178.

LE GALL 1976: J. Le Gall, «Evocatio», in L'Italie préromaine et la Rome républicaine. I. Mélanges offerts à Jacques Heurgon, Rome 1976, 519-524.

LEVENE 1993: D. S. Levene, Religion in Livy, Leiden 1993.

LIEBESCHUETZ 1967: W. Liebeschuetz, «The Religious Position of Livy's History», Journal of Roman Studies 57 (1967), 45-55. 
MACKAY 1956: L. A. MacKay, «Saturnia Iuno», Greece and Rome, Second Series 3.1, (1956), 59-60. Mignone 2016: L. M. Mignone, The Republican Aventine and Rome's Social Order, Ann Arbor 2016. Most 2001: G. W. Most, «Memory and Forgetting in the Aeneid», Vergilius 47 (2001), 148-170. MuSIAŁ AND GILLMEISTER 2018: D. Musiał and A. Gillmeister, «Evocatio deorum as an Example of a Crisis Ritual in Roman Religion», Graeco-Latina Brunensia 23.2 (2018), 95-107.

MYNORS 1969: R. Mynors, Vergili Maronis Opera, Oxford 1969.

OGILVIE 1978: R. M. Ogilvie, A Commentary on Livy. Books 1-5, Oxford 1978.

ORLIN 2002a: E. Orlin, «Foreign Cults in Republican Rome: Rethinking the Pomerial Rule», Memoirs of the American Academy in Rome 47 (2002), 1-18.

ORLIN 2002b: E. Orlin, Temples, Religion, and Politics in the Roman Republic, Leiden 2002.

ORLIN 2010: E. Orlin, Foreign Cults in Rome. Creating a Roman Empire, Oxford 2010.

PRIM 2021: J. Prim, Aventinus mons. Limites, fonctions urbaines et représentations politiques d'une colline de la Rome antique, Rome 2021.

SCHEID 2015: J. Scheid, «Livy and Religion», in B. Mineo (ed.), A Blackwell Companion to Livy, Oxford 2015, 78-89.

SEIDER 2013: A. M. Seider, Memory in Vergil's Aeneid. Creating the Past, Cambridge 2013.

SYED 2005: Y. Syed, Vergil's Aeneid and the Roman Self. Subject and Nation in the Literary Discourse, Ann Arbor 2005.

TARRANT 2012: R. Tarrant, Virgil Aeneid Book XII, Cambridge 2012.

THILO AND HAGEN 1887 (1961): G. Thilo and H. Hagen, Servii Grammatici qui feruntur in Vergilii Carmina Commentarii, Leipzig 1887 (repr. Hildesheim 1961).

TOLL 1991: K. Toll, «The Aeneid as an Epic of National Identity: Italiam Laeto Socii Clamore Salutant», Helios 18 (1991), 3-14.

TOLL 1997: K. Toll, «Making Roman-ness and the Aeneid», Classical Antiquity 16.1, (1997), 34-56.

TORELLI 1999: M. Torelli, Tota Italia. Essays in the Cultural Formation of Roman Italy, Oxford 1999.

WARRIOR 2006: V. Warrior, Livy. The History of Rome. Books 1-5, Indianapolis 2006.

WEIGEL 1982/1983: R. D. Weigel, «The Duplication of Temples of Juno Regina in Rome», Ancient Society 13/14 (1982/1983), 179-192.

WILLIS 1994: J. Willis, Ambrosii Theodosii Macrobii Saturnalia, Leipzig 1994.

WIMPERIS 2017: T. Wimperis, Cultural Memory and Constructed Ethnicity in Vergil's Aeneid, PhD dissertation, Chapel Hill 2017.

\section{NOTES}

1. References and quotations from the text correspond to the edition by MYNORS (1969). On Juno's memory, see especially SEIDER 2013, 66-75 and 171-175.

2. The terms "historical" and "mythical" are employed as in FEENEY 1984, 183.

3. The shipwreck in Book 1, the love plot with Venus in Book 4 (which aims at making Aeneas stay in Carthage, the sending of Alecto in Book 7, but ends up causing the outbreak of the war in 
Latium), and the inflammation of Turnus through Iris in Book 9, are among the main episodes in which Juno intervenes.

4. CAIRNS 1989, 105: "The stress by Jupiter on the sibling relationship between Juno and himself (12.830) which complements the emphasis placed by him on their conjugal state at the beginning of their discussion (12.793), redoubles the significance of their concord. Jupiter then 'yields' to Juno even though he has defeated her, an example of the 'no victors' concept". Cf. also SEIDER $2013,172$.

5. 12.829-830: es germana Iouis Saturnique altera proles, / irarum tantos uoluis sub pectore fluctus. I agree with TARRANT 2012: 302: “Jupiter seems almost to admire the intensity of Juno's anger as a shared family trait. His easy acceptance of divine wrath is literally a world away from V.'s question (1.11) tantaene animis caelestibus irae?"

6. According to TARRANT 2012, 303, this is a paradox that suggests that, in the end, Jupiter is still in control.

7. 12.834-837: sermonem Ausonii patrium moresque tenebunt, / utque est nomen erit; commixti corpore tantum / subsident Teucri, morem ritusque sacrorum / adiciam faciamque omnis uno ore Latinos. Regarding concepts such as "Ausonians" or "Latins", see ANDO 2002, 139-140; S YED 2005, 206; BETTINI 2005, 78-85 especially n. 8 and n. 10; TARRANT 2012, 303. About the question of ethnicity in Vergil's Italy, see Toll 1991, CANCIK 2004, AMES AND DE SANTIS 2011.

8. 12.838-840: hinc genus Ausonio mixtum quod sanguine surget, / supra homines, supra ire deos pietate uidebis, / nec gens ulla tuos aeque celebrabit honores. TARRANT $(2012,305)$ highlights Jupiter's rhetorical skill - he does not promise that she will be the most venerated deity in Rome, since he is Optimus Maximus, but that no other nation will worship her with a better cult than the Romans. Juno's concern in 1.48-49 (et quisquam numen Iunonis adorat / praeterea aut supplex aris imponet honorem?) is therefore eliminated.

9. JoHnson $(1976,126)$ presents different interpretations of laetata. It is possible that Juno is satisfied because of the cult that she will receive in the future, or perhaps she is happy that she could reach her goal, or maybe her satisfaction is based on the suffering that the Romans will go through during the Punic wars.

10. Cf. Serv. ad Aen. 12.841. OGILVIE $(1978,674)$, in his introduction to 5.21, observes that the word exoratio used by Servius implied that the deity was persuaded to change his allegiance but not his home, while evocatio included the agreement to leave the original city and have a new home in Rome. ANDo $(2008,129$ n. 25) believes that the word exoratio does not have a technical meaning.

11. Cf. FEENEY 1984, 179-181.

12. About the historicity of this episode, cf. BERTI 1990, 71-75; FERRI 2009, 185-187; GRANDI 2015, 27-28.

13. References and quotations from Macrobius' text follow the edition by WiLLIS 1994.

14. This translation is quoted from DAVIES 1969.

15. About these two possible grounds for the evocatio ritual, cf. DuMÉZIL 1974, 425; BERTI 1990, 69; GUSTAFSSON 2000, 132-133; FERRI 2010a, 39-41.

16. Macrobius states (Sat. 3, 9.6) that he took the carmen from a treatise by Samonicus Serenus, who in turn claimed to have drawn it from Furius (repperi in libro quinto Rerum reconditarum Sammonici Sereni utrumque carmen, quod ille se in cuiusdam Furii vetustissimo libro repperisse professus est). According to AlVAR $(1985,255)$, this text was no longer used in Macrobius' time. The author quotes a Republican exemplum, the one of the conquest of Carthage in $146 \mathrm{BCE}$, to prove that he is drawing upon scholarly knowledge. For a detailed analysis of the carmen, cf. FERRI 2010b and GRANDI 2015, 30-31.

17. According to BERTI 1990, 70 it is possible that Livy modeled his account of the taking of Veii on the basis of a tradition referring to the ritual celebrated by Scipio. 
18. As fundamental studies for the study of the evocatio ritual, cf. AlVAR 1985, BERTI 1990, BLOMART 1997, GUSTAFSSON 2000, FERRI 2006, ANDO 2008, FERRI 2008, FERRI 2009, FERRI 2010a, FERRI 2010b, and GRANDI 2015.

19. AlVAR 1985, 265 and BlOMART 1997, 100-102 point out that it is possible to have evocationes in non-war contexts.

20. I will not refer here to the problem of the secret name of tutelar deities; see ALVAR 1985; GUSTAFSSON 2000, 129-134; FERRI 2010a, 101-128; FERRI 2010b, 157-222.

21. About the centrality of cult images for this ritual, cf. BLOCH 1972, 388-389 and FERRI 2010a, 41. According to BLOMART 1997, 101, evocatio was a frequent ritual, but it did not always involve the transfer of the statue to Rome. See also GuSTAFSSON 2000, 80.

22. GuSTAFSSON $(2000,81)$ states that the important features of the evocatio ritual were the war context and the votum, more than the image transfer. In the conclusions of her study (153-154), she expresses her reservations regarding understanding evocatio as a fixed practice, with a specific ritualization, given the scarcity of testimonies: "Obviously, there had been a strong tradition that deities had been 'called out' before a decisive attack on a city that was to be conquered by the Romans, possibly in accordance with a specific ritual formula. We do not know, however, in what ways such a possible ritual might have been regulated, when and where it could be applied or how it may have developed during the course of Roman history".

23. The bibliography discusses whether it is an exceptional or a frequent ritual. BOUCHÉ-LECLERCQ 1907, 573 and GLINISTER 2000, 62 believe it was an exception, while ALVAR 1985, 255, BLOMART 1997, 100, and GRANDI 2015, 28 defend the second option. FERRI 2010a, 58 proposes a halfway solution: "Si può pertanto formulare l'ipotesi che, in occasione degli assedi, si evocassero gli dèi protettori della città con una certa frequenza, [...] e che la decisione fosse presa caso per caso, alla luce delle particolari e contingenti motivazioni belliche o religiose". About devotio hostium as a complement of evocatio, see LE GALL 1976, 524; GUSTAFSSON 2000, 65-70; FERRI 2006, 214-216; ANDO 2008, 130.

24. About the Roman system of incorporation of foreign gods and cults, cf. BLOCH 1972, 391; BEARD, NoRTH AND PRICE 1998, 132-133; ORLIN 2002a, 2; ORLIN 2010; FERRI 2010a, 43-44.

25. FERRI (2010a, 39) mentions three records of this ritual: a) Iuno Regina from Veii in $396 \mathrm{BCE}, \mathrm{b}$ ) Iuno Caelestis from Carthage in $146 \mathrm{BC}$, and c) the tutelary deity from Isaura Vetus in $75 \mathrm{BCE}$. GustAFsSON $(2000,63)$ argues that the evidence about the ritual is scarce because the testimonies are too late in relation to the events to which they refer.

26. Cf. ORLIN 2002b, 15: "The addition of new gods functioned as a conscious display of Rome's growing power. The establishment of a foreign cult in Rome served as a mark of Roman domination of the deity's country of origin; even its gods have been brought to Rome".

27. Opinions regarding the effective transfer of Juno's simulacrum to Rome differ. According to DuMÉzIL (1974, 468), the image was housed in Juno Moneta's temple. GRANDI (2015, 56-57) contemplates this option, as well as the possibility that it was transferred, or that it was assimilated to another divinity of the Carthaginian pantheon - perhaps Melquart, the Phoenician parallel to Heracles, which would explain the construction of a temple to Heracles in the Forum Boarium in $142 \mathrm{BC}$.

28. About Iuno Caelestis, cf. FERRI 2009 and FERRI 2010b, 87-108. The epithet Caelestis points to an astrological character ( $\mathrm{cf}$. BLoch 1972, 394) that makes possible the interpretatio of Juno as equivalent to the Carthaginian goddess Tanit (FERRI 2009, 190-192).

29. The English translation of the Aeneid is quoted from AHL 2007.

30. 1.446-447: hic templum Iunoni ingens Sidonia Dido / condebat, donis opulentum et numine diuae.

31. For a summary of the historical context of the conquest of Veii, see OGILVIE 1978, 626-630.

32. Cf. DumÉzIL 1974, 299-309. See also HILD 1900, 682.

33. About Juno's temples in Rome, cf. DuMÉzIL 1974, 301-302 and 426; WEIGEL 1982/1983; ORLIN 2010, 37; TARRANT 2012, 305. FERRI $(2010 \mathrm{a}, 52)$ observes that the deities who had temples in the 
Aventine Hill were defined by their alterity and marginal character. For detailed discussions of the sanctuaries on the Aventine, including the temple dedicated to Juno Regina, see PRIM 2021 (esp. 349-468); cf. also Mignone 2016, 5, 45, 96, 120, 182-183.

34. BLOCH 1972, 391.

35. About the identification of the goddesses, see OGILVIE 1978, 674; FEENEY 1993, 116; FERRI 2010a, 22.

36. References and quotations from the text correspond to the edition by HILLEN 2007. For an analysis of Juno's evocatio in Livy, see chapter 5 in GUSTAFSSON 2000 and F ERRI 2010b, 55-86. Another account of this episode can be found in Plut., Cam. 6-7.

37. Cf. LEVENE 1993, 176-177.

38. Cf. V.1.6-7: Gens itaque ante omnes alias eo magis dedita religionibus quod excelleret arte colendi eas, auxilium Veientibus negandum donec sub rege essent decrevit; cuius decreti suppressa fama est Veiis propter metum regis qui a quo tale quid dictum referretur, pro seditionis eum principe, non vani sermonis auctore habebat. OGILVIE $(1978,626)$ observes: "Book 5 illustrates how the fortunes of the city veer as her rulers observe and neglect their religious duties. [...] Veii fell because of her own impiety (1.4-5) and Roman piety (15.2, 19.1ff, 21.8)". In similar terms, cf. SCHEID 2015, 79.

39. Cf. V.13.4-6: tristem hiemem sive ex intemperie caeli, raptim mutatione in contrarium facta, sive alia qua de causa gravis pestilensque omnibus animalibus aestas excepit; cuius insanabili perniciei quando nec causa nec finis inveniebatur, libri Sibyllini ex senatus consulto aditi sunt. duumviri sacris faciundis, lectisternio tunc primum in urbe Romana facto, per dies octo Apollinem Latonamque et Dianam, Herculem, Mercurium atque Neptunum tribus quam amplissime tum apparari poterat stratis lectis placauere. Cf. OGILVIE 1978, 654-658.

40. Cf. Livy 5.15.7-12: cumque progressi ambo a suis longius essent inermes sine ullo metu, praevalens iuvenis Romanus senem infirmum in conspectu omnium raptum nequiquam tumultuantibus Etruscis ad suos transtulit. qui cum perductus ad imperatorem, inde Romam ad senatum missus esset, sciscitantibus quidnam id esset quod de lacu Albano docuisset, respondit profecto iratos deos Veienti populo illo fuisse die quo sibi eam mentem obiecissent ut excidium patriae fatale proderet. itaque quae tum cecinerit divino spiritu instinctus, ea se nec ut indicta sint revocare posse, et tacendo forsitan quae di immortales volgari velint haud minus quam celanda effando nefas contrahi. sic igitur libris fatalibus, sic disciplina Etrusca traditum esse, [ut] quando aqua Albana abundasset, tum si eam Romanus rite emisisset victoriam de Veientibus dari; antequam id fiat deos moenia Veientium deserturos non esse. exsequebatur inde quae sollemnis derivatio esset; sed auctorem levem nec satis fidum super tanta re patres rati decrevere legatos sortesque oraculi Pythici exspectandas. Cf. OGILVIE 1978, 660-663.

41. Cf. Livy 5.18.11-12: his tumultuosiora Romae, iam castra ad Veios oppugnari, iam partem hostium tendere ad urbem agmine infesto, crediderant; concursumque in muros est et matronarum, quas ex domo conciverat publicus pavor, obsecrationes in templis factae, precibusque ab dis petitum ut exitium ab urbis tectis templisque ac moenibus Romanis arcerent Veiosque eum averterent terrorem, si sacra renovata rite, si procurata prodigia essent. Note the prominence of matronae, which can be interpreted as an advance of the cult of Juno Regina.

42. Cf. Livy 5.19.6: quibus cum gratias in senatu egisset dictator, satis iam omnibus ad id bellum paratis, ludos magnos ex senatus consulto vovit Veiis captis se facturum aedemque Matutae Matris refectam dedicaturum, iam ante ab rege Ser. Tullio dedicatam.

43. Cf. GuSTAFSSON 2000, 93-94.

44. Torelli $(1999,24-25)$ points out that terracotta statuettes of Aeneas carrying Anchises were found in the main sanctuaries of Veii. This archaeological evidence points to a strong presence and circulation of the Trojan myth in this region, which can support the idea of a parallelism between the Trojan war and the conquest of Veii: "the colonization of Veii was brought about in the mythical framework of the Trojan legend and [...] the awareness of such an ideological 
stimulus spread to the lowest levels of society, to which we must ascribe the dedicators of the statuettes".

45. Cf. Liebeschuetz 1967, 53; GustafsSon 2000, 96, 112-128; GAERTNER 2008, 36-37. O Gilvie (1978, 670) identifies some features in the character of Camillus that present him as one of the many exemplary men of Roman history: Aeneas, Scipio, Sulla, Augustus. Moreover, there are many elements that connect the account of the conquest of Veii with the Trojan war - the ten-year siege, the central role of fatum, the final conquest through a stratagem, which allows this Republican episode to be presented in epic terms. EGAN $(2012,25)$ connects Camillus not only to Aeneas, but also with Romulus and Augustus himself: "Camillus, a savior of the old Rome and founder of the new, bisects Roman history between Romulus' foundation and $27 \mathrm{BC}$, the signal year for Octavian/Augustus".

46. Cf. HiCKSON (1993, 17-19). The poetic influence of Homer and Ennius is especially noticeable in prayers, the main topic of Hickson's study. FRATANTUONO (2018) presents Livy's Camillus as an inspiration for both Virgil's Camilla and Turnus.

47. This translation is quoted from WARRIOR 2006.

48. Cf. Livy 5.22.4: delecti ex omni exercitu iuvenes, pure lautis corporibus, candida veste, quibus deportanda Romam regina Iuno adsignata erat.

49. Livy 5.22.5: id signum more Etrusco nisi certae gentis sacerdos attractare non esset solitus. See OGILVIE 1978, 678 and ORLIN 2010, 39.

50. Cf. Livy 5.22.6: sequentis modo accepimus levem ac facilem tralatu fuisse.

51. Cf. ORLIN 2010, 38.

52. Cf. Livy 5.22.7: integramque in Aventinum aeternam sedem suam quo vota Romani dictatoris vocaverant perlatam, ubi templum ei postea idem qui voverat Camillus dedicavit.

53. The ignorance of the people from Veii is described in Livy 5.21.5-7: Veientes ignari se iam a suis vatibus, iam ab externis oraculis proditos, iam in partem praedae suae vocatos deos, alios votis ex urbe sua evocatos hostium templa novasque sedes spectare, seque ultimum illum diem agere, nihil minus timentes quam subrutis cuniculo moenibus arcem iam plenam hostium esse, in muros pro se quisque armati discurrunt, mirantes quidnam id esset quod cum tot per dies nemo se ab stationibus Romanus movisset, tum velut repentino icti furore improvidi currerent ad muros. See OGILVIE $(1978,675)$ : the use of ignari refers to the conquest of Troy in Aeneid 2; there are probably Ennian resonances in both texts.

54. See SEIDER 2013, 174-175: “Juno's words imply that Rome and Troy cannot co-exist, even that Rome cannot exist if it contains any Trojan characteristics. With the Trojans' name, language, and dress gone, so too is the prospect for the continuation of any rituals that may carry on their social memory. [...] Her repetition of the verb "die" (occidit, occiderit) leaves no doubt as to her wishes, and the climactic placement of "Troy" (Troia) affirms what is at the core of her wrath. In spite of Troy's physical destruction, the Trojans have been keeping the city alive by commemorating it in spirit. This has only exacerbated Juno's anger, and now she wants to ensure the complete annihilation of both the city and its name. Troy is the final word of her speech and the final word she speaks in the Aeneid, and it brings the epic back to the memories that motivated her anger in Aeneid 1 and reaffirms that they still motivate it now in Aeneid 12". See also ANDO 2002, 139.

55. About the meaning of the mentions to Latium and Italy in this passage, Cf. SYED 200, 206; BETTINI 2005, 77-85; WIMPERIS 2017, 211-214. SEIDER $(2013,174)$ examines in detail the problem of the oblivion of Troy. In Juno's request, it is important to understand the emphasis on virtus as an intrinsically masculine feature, in contrast to the frequent feminization suffered by the Trojans. A clear example of this contrast can be found in Numanus Regulus' speech in Aen. 9.598-620.

56. Cf. JOHNSTON 1980, 75 and SEIDER 2013, 176-177.

57. 8.322-323: Latiumque vocari / maluit, his quoniam latuisset tutus in oris. Cf. EDEN 1975, 107-108 and FRATANTUONO-ALDEN SMITH 2018, 426-428. 
58. Cf. JOHNSTON 1980, 74.

59. MACKAY 1956, 60: "It can hardly be accidental that the name Saturnia is applied to Juno chiefly in the part of the poem where her chief activity is the direct defence of the old order, the native traditions, the indigenous element of the Saturnia tellus". See also JoHNSTON 1980, 75 and 88.

60. Cf. HENRY 1989, 171.

61. RG 19: curiam et continens ei Chalcidicum templumque Apollinis in Palatio cum porticibus, aedem divi Iuli, Lupercal, porticum ad circum Flaminium, quam sum appellari passus ex nomine eius qui priorem eodem in solo fecerat, Octaviam, pulvinar ad circum maximum, aedes in Capitolio Iovis Feretri Iovis Tonantis, aedem Quirini, aedes Minervae et Iunonis Reginae et Iovis Libertatis in Aventino, aedem Larum in summa sacra via, aedem deum Penatium in Velia, aedem Iuventatis, aedem Matris Magnae in Palatio feci.

62. TARRANT $(2012,305)$ disagrees and considers it unnecessary: "a happy Juno is a sinister enough note on which to end".

63. See, for example, the dialogue between Jupiter and Cybele in Aen. 9.80-106.

64. Regarding the alleged contradiction between what Jupiter states here, and his speech to Venus in Book 1, see CAIRo 2016.

\section{ABSTRACTS}

This paper aims to examine the dialogue between Juno and Jupiter in Aen. 12.791-842 in terms of a rite of evocatio. The reconciliation of Juno with her husband has been analyzed by D. Feeney in his classic 1984 article, in which it is argued that in this passage Virgil follows the Ennian tradition, according to which Juno is finally placated by Scipio's sacrifices at the end of the Third Punic War. In this passage it is possible to see an allusion not only to the Punic Wars, but also to the conflicts between Rome and other Italian cities during its expansion in the Republican period - in particular, to the episode of the conquest of the Etruscan city of Veii. It is argued here that this episode of evocatio is especially remembered in Aeneid 12, considering that in the second half of the poem Juno is described mostly as an Italian deity, and that in this dialogue she asks Jupiter to ensure the pre-eminence of the Italic characters in the configuration of the future Roman identity.

Questo articolo si propone di esaminare il dialogo tra Giunone e Giove in Aen. 12.791-842, nei termini di un rito di evocatio. La riconciliazione di Giunone con il marito è stata analizzata da D. Feeney nel suo articolo ormai classico del 1984, in cui si sostiene che in questo passo Virgilio segue la tradizione enniana, secondo la quale Giunone viene finalmente placata dai sacrifici di Scipione alla fine della terza guerra punica. In questo passo è possibile vedere un'allusione non solo alle guerre puniche, ma anche ai conflitti tra Roma e altre città italiche durante la sua espansione nel periodo repubblicano - in particolare, all'episodio della conquista della città etrusca di Veio. Si sostiene qui che questo episodio di evocatio sia particolarmente ricordato nell'Eneide 12, considerando che, nella seconda parte del poema, Giunone è descritta soprattutto come una divinità italica, e che, in questo dialogo, la dea chiede a Giove che siano i tratti italici a prevalere nella futura configurazione dell'identità romana. 
INDEX

Keywords: Juno, evocatio, cult images, Italian religion

Parole chiave: Giunone, evocatio, immagini di culto, religione italica

\section{AUTHOR}

\section{MARÍA EMILIA CAIRO}

Universidad Nacional de La Plata, Argentina

Consejo Nacional de Investigaciones Científicas y Técnicas Argentina Calle 58 № 867 , dto C

1900 La Plata

Pcia. de Buenos Aires

República Argentina

emiliacairo@conicet.gov.ar 